\title{
Investigation Effects of Some Heart Disorder Drugs on Human Carbonic Anhydrase I
}

\author{
Insan Karbonik Anhidraz I Üzerine Bazı Kalp Rahatsızlık \\ İlaçlarının Etkilerinin İncelenmesi
}

\author{
Research Article \\ Sibel Tuğral Kaplan', Mehmet Kuzucu', Nurdagül Aktaş², Esra Dilek³ ${ }^{3}$ Murat Çankayaa*, \\ Taha Abdullkadir Çoban ${ }^{4}$
}

'Science and Art Faculty, Department of Biology, Erzincan University, Erzincan, Turkey.

${ }^{2}$ Medicine Faculty, Department of, Physical Medicine and Rehabilitation University, Erzincan, Turkey.

${ }^{3}$ Pharmacy Faculty, Department of Biochemistry, Erzincan University, Erzincan, Turkey.

${ }^{4}$ Medicine Faculty, Department of Biochemistry, Erzincan University, Erzincan, Turkey.

\section{ABSTRACT}

$\mathrm{n}$ the treatment of heart disorders, metoprolol tartrates and digoxin drugs which act by way of blood are used widely. Being vital of using these drug substances, investigation of inhibitory effect on the activities of enzymes in the blood reveals the importance of this work. Aim of this study to investigate effects of metoprolol tartrate and digoxin on human erythrocyte carbonic anhydrase I isoenzyme in vitro conditions. CA-I isoenzyme from human blood has been purified using Sepharose-4B-I-tyrosine-sulfanilamide affinity chromatography method. The enzyme was purified $\sim 116$-fold with a yield of $62 \%$. At the end of inhibition studies two substances were showed uncompetitive inhibition. $\mathrm{K}_{\mathrm{i}}$ values were determined metoprolol tartrate $5.49 \pm 1.86 \mathrm{mM}$ and digoxin $0.0914 \pm 0.0062 \mathrm{mM}$.

\section{Key Words}

Carbonic anhydrase I, affinity chromatography, drug, inhibition.

\section{öz}

\begin{abstract}
Kalp rahatsılıklarının tedavisinde, kan yolu ile etki gösteren metoprolol tartarat ve digoksin ilaçları yaygın - bir şekilde kullanılmaktadır. Bu ilaç etken maddelerinin kullanımının hayati öneme sahip olması, bunların kanda bulunan enzimlerin aktiviteleri üzerine inhibisyon etkilerinin araştırılması bu çalışmanın önemi ortaya koymaktadır. Bu çalışmada hedeflenen, metoprolol tartarat ve digoksin ilaç etken maddelerinin insan eritrositi karbonik anhidraz I (CA-I) izoenzimi üzerine in vitro etkilerinin araştırılmasıdır. CA-I izoenzimi Sefaroz-4BL-tirozin-sülfamid afinite kromatografisi yöntemi ile insan eritrositlerinden saflaştırıldı. CA-ı izoenzimi \%62 verimle yaklaşık 115 kat saflaştırılmıştır. İnhibisyon çalışmaları sonucunda iki inhibitör de yarışmasız inhibisyon göstermiştir. $K_{i}$ değerleri metoprolol tartarat $5.49 \pm 1.86 \mathrm{mM}$ ve digoksin için $0.0914 \pm 0.0062 \mathrm{mM}$ olarak belirlenmiştir.
\end{abstract}

\section{Anahtar Kelimeler}

Karbonik anhidraz I, afinite kromotografisi, ilaç, inhibisyon.

Article History: Received: Aug 3, 2016; Revised: Sep 9, 2016; Accepted: Sep 20, 2016; Available Online: Apr 1, 2017

DOI: 10.15671/HJBC.2017.156

Correspondence to: M. Çankaya, Science and Art Faculty, Department of Biology, Erzincan University, Erzincan, Turkey. 


\section{INTRODUCTION}

arbonic anhydrase is from metalloenzymes family (Carbonate hydrolysis, CA, E.C.4.2.1.1) has zinc $\left(\mathrm{Zn}^{2+}\right)$ ion in the active site. Isozymes of carbonic anhydrase are an enzyme family that catalyzes the conversion reaction carbon dioxide and bicarbonate to protons. In red blood cells, carbonic anhydrase isoenzymes which are found in many tissues in mammals and plants, enzymes that crumbling carbonic acid via carbon dioxide and water. The molecular mass of the enzyme on mammalians was confirmed to be about $30 \mathrm{kDa}$ [1-5].

The structure of the genes specified in the human CA isoenzymes and it was discovered that vital functions of these enzymes vary according to tissues and organs. CA enzyme was characterized in most of these tissues and their functions were tried to be determined. The existence of enzyme was determined in consequence of investigation of CA isoenzymes that are generally found in human. CA I exists in human red blood cells. When CA I purified in human blood, its quantity was calculated as $12 \mathrm{mg} / \mathrm{g}$ hemoglobin, the turnover number of CA I isoenzymes were $2.5 \times 10^{5} \mathrm{~S}^{-1}[6]$.

Enzymes are responsible for numerous biochemical reactions required for performing the vital activities of living organisms. Capability of catalyzing the biochemical reaction separates enzymes from other protein molecules [7]. Thanks to this capability it is a source of interest in field of studies. By linking to the enzymes in vivo and in vitro some compounds found in nature, reducing their activity or completely eliminate the phenomenon is called inhibition. Compounds that lead to this phenomenon are called inhibitors. Inhibitors are generally compounds that have low molecular weight or ions. Inhibition of enzymatic activity creates a control mechanism on itself in biological systems. Many drugs and toxic compounds perform their effects in this way [8].

Inhibitors are important for both enlightening metabolic pathways and mechanism of action of the enzyme. Therefore to assist action mechanism of the drugs which are used for treatment and to ensure benefits for further investigations many enzyme inhibition studies with different drugs have been reported till today [9-14]. The objective of this study is determining in vitro interaction between the CA I isoenzyme and two drug active agents that are used in the treatment of heart diseases.

\section{EXPERIMENTAL}

\section{Materials}

Sepharose 4B, protein analysis reactive and 4-nitrophenyl acetate was obtained from SigmaAldrich Co. The other chemicals were obtained from Merck.

\section{Purification of Carbonic Anhydrase Isoenzyme from Human Blood}

Human blood used in the experiment was obtained from Erzincan Mengücek Gazi Education and Research Hospital. The blood, after receiving the anticoagulated blood bags was stored at $4^{\circ} \mathrm{C}$. The procedures implemented in previous studies were performed $[1,2]$. Respectively, erythrocytes were separated from human blood and hemolyzed with cold pure water. In order to separate cell membrane, hemolysate was centrifuged at $20.000 \mathrm{rpm}$ at $4^{\circ} \mathrm{C}$ for one half hour. The $\mathrm{pH}$ of the hemolysate that was separated from the cell membranes was adjusted to 8.7 with solid Tris. In this way, hemolysate became to be applied to column. Activated with $\mathrm{CNBr}$ Sepharose-4B was activated by L-tyrosine. After washing with $100 \mathrm{ml}$ $0.2 \mathrm{M} \mathrm{NaHCO}_{3}(\mathrm{pH} 8.80$ ) buffer, column material was taken into $40 \mathrm{ml}$ of this same buffer. Diazotized Sulfanilamide was added to a suspension of $40 \mathrm{ml}$ Sepharose-4B-L-tyrosine. It was suspended by taking up into prepared gel equilibration buffer (Tris- $\mathrm{HCl}, \mathrm{pH}=7.8$ ). The suspended gel was packed to cooled column consisting of $1 \times 10 \mathrm{~cm}$ closed system and it was washed with balancing buffer.

Solid Tris and hemolysate $(\mathrm{pH}$ 8.7) were applied to the column and the column was washed with a solution of $400 \mathrm{ml} 25 \mathrm{mM}$ Tris- $\mathrm{HCl} / 22 \mathrm{mM}$ $\mathrm{Na}_{2} \mathrm{SO}_{4}(\mathrm{pH}: 8.7)$. By this way, CA I isoenzyme attached to the column and it was detracted from other impurities. Then by applying $\mathrm{M} \mathrm{NaCl} / 25 \mathrm{mM}$ $\mathrm{Na}_{2} \mathrm{HPO}_{4}$ ( $\mathrm{pH}$ 6.3) buffer CA I isoenzymes were eluted. With the help of fraction collector eluates were taken up into $5 \mathrm{ml}$ tubes. The amount of protein and activity values was examined for each 
tube. In order to do kinetic studies by combining the tubes that activate were stored at $4^{\circ} \mathrm{C}$.

\section{Determination of Esterase Activity}

This method is based on the CA enzymes that have esterase activity. In principle CA I hydrolyzing the p-nitrophenyl acetate used as substrate and that provides absorption at $348 \mathrm{~nm}\left(\varepsilon 348=5 \times 10^{-3} \mathrm{M}^{-1}\right.$ $\mathrm{cm}^{-1}$ ) [15].

Following procedure was applied in the determination process; enzyme solution that was buffered to quartz tub $\left(0.05 \mathrm{M}\right.$ Tris- $\mathrm{SO}_{4} \mathrm{pH}$ of 7.4) and after 3 minutes the addition $1.5 \mathrm{ml}$ of substrate (+ inhibitor) $25^{\circ} \mathrm{C}$ the absorbance value at $348 \mathrm{~nm}$ was read. P-nitrophenyl acetate used in this experiment was prepared daily. P-nitrophenyl acetate $27 \mathrm{mg}$ p-nitrophenyl acetate was weighed and it was dissolved in $1 \mathrm{ml}$ acetone and it was added slowly to the $49 \mathrm{ml}$ of rapidly stirred distilled water.

\section{Protein Determination by Bradford Method}

The enzyme solution purified via affinity chromatography and the amount of protein in hemolysate was determined by this method. This method based on binding of proteine coomassie brillant blue G-250. Formed complex indicates the maximum absorbance at $595 \mathrm{~nm}$. The sensitivity of this method is $1-100 \mu \mathrm{g}$ [16].

\section{Checking the Enzyme Purity by SDS- Polyacrylamide Gel Electrophoresis}

After purification the enzyme 3-8\% intermittent sodium dodecyl sulfate polyacrylamide gel electrophoresis (SDS-PAGE) The purity of the enzyme was checked according to the Laemmli method [17].

\section{RESULTS and DISCUSSION}

Carbonic anhydrase (CA, Soda hidroliyaz E.C. 4.2.1.1) enzyme containing erythrocytes is a $\mathrm{pH}$ regulator that was well characterized enzyme in most tissues. It catalyzes the conversion of carbon dioxide to bicarbonate and proton. This is a quite rapid reaction [18]. Carbonic anhydrase increase the speed of this reaction extremely and increase it to $10^{4}-10^{6}$ reaction speed per second [19].

In this study, human erythrocyte carbonic anhydrase isoenzyme (CA-I) was purified with affinity chromatography. Inhibitory effects of active ingredients of some drugs used for the treatment of heart diseases on this isoenzyme were determined in vitro.

CA I isoenzymes purified 115.64 times from humanbloodviamethod of affinity chromatography and $62 \%$ yield, specific activity 1062.75 (Eu/mg protein) (Table 1). Upon the purified CA-I activity inhibitory effect of metoprolol tartrate and digoxin active substance were examined. Activity against inhibitor concentration (\% activity configures [I]) graphics were drawn (Figure 1). $I C_{50}$ values were calculated from the equation of curves. These values are calculated as $5.036 \mathrm{~mm}$ for metoprolol tartrate, $0.045 \mathrm{~mm}$ for digoxin (Table 2). In order to determine $K_{i}$ values of active substance used in the study. Activity values were examined in three constant inhibitory concentrations that were determined against 3 different substrate

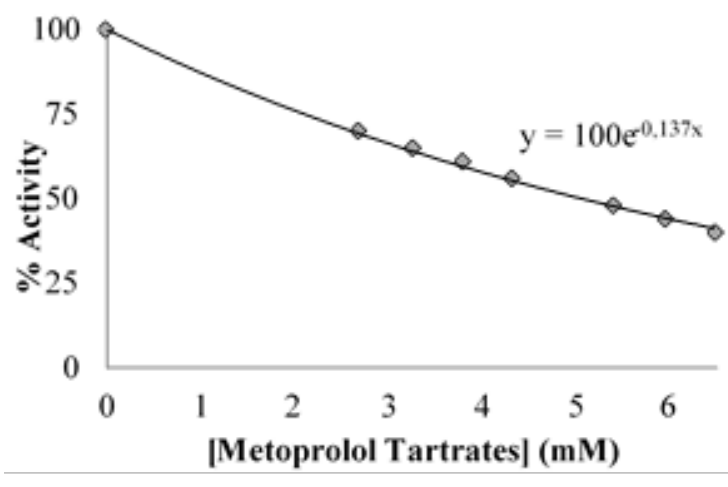

A

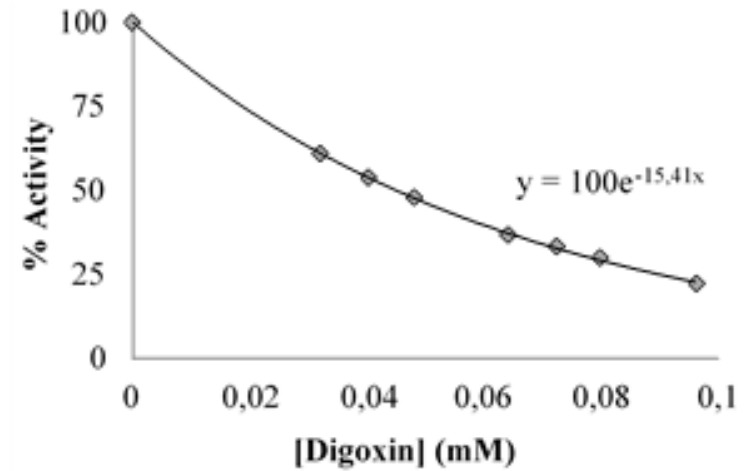

B

Figure 1. \% Activity-[drug] graphs for CA I for two drugs: (A) Metoprolol Tartrates and (B) Digoxin. 
Table 1. Purification steps of Human Carbonic Anhydrase I.

\begin{tabular}{lcccccc}
\hline Purification steps & $\begin{array}{c}\text { Total } \\
\text { volume } \\
(\mathrm{mL})\end{array}$ & $\begin{array}{c}\text { Enzyme } \\
\text { activity } \\
(\mathrm{EU} / \mathrm{mL})\end{array}$ & $\begin{array}{c}\text { Protein } \\
(\mathrm{mg} / \mathrm{ml})\end{array}$ & $\begin{array}{c}\text { Specific } \\
\text { activity } \\
(\mathrm{EU} / \mathrm{mg}))\end{array}$ & $\begin{array}{c}\text { Recovery } \\
(\%)\end{array}$ & Purification fold \\
\hline Homogenate & 48.00 & 162.00 & 17.63 & 9.19 & 100 & 1.00 \\
\hline CA-I & 7.50 & 542.00 & 0.51 & 1062.75 & 62 & 115.64 \\
\hline
\end{tabular}

Table 2. $I C_{50}$ values, $K_{i}$ constant and inhibition type of Metoprolol Tartrates and Digoxin as inhibitor of CA I

\begin{tabular}{lccc}
\hline Inhibitor & $\mathrm{IC}_{50}$ value $(\mathrm{mM})$ & $\begin{array}{c}\mathrm{K}_{\mathrm{i}} \text { constant } \\
(\mathrm{mM})\end{array}$ & Inhibition type \\
\hline Metoprolol Tartrates & 5.036 & $5.49 \pm 1.86$ & Non-competitive \\
\hline Digoxin & 0.045 & $0.0914 \pm 0.0062$ & Non-competitive \\
\hline
\end{tabular}

concentrations and Lineweaver-Burk graphs were drawn for each inhibitor (Figure 2) [20]. With the help of these graphs Inhibition types and $\mathrm{K}_{\mathrm{i}}$ values were determined. Both of two active substances indicated noncompetitive inhibition. $\mathrm{K}$ values calculated as $5.49 \pm 1.86 \mathrm{mM}$ for metoprolol tartrate and $0.0914 \pm 0.0062 \mathrm{mM}$ for digoxin (Table 2). SDS-polyacrylamide gel electrophoresis was applied to check the purity of the CA I isoenzymes that was purified. In electrophoresis, a single band was observed for the CA I (Figure 3).

Drugs containing metoprolol tartrate are used in order to control of blood pressure in humans and relieve the symptoms of angina. Drugs containing digoxin is a cardiac glycosides that commonly used for cardiac insufficiency and speed control in atrial fibrillation. It provides increase of

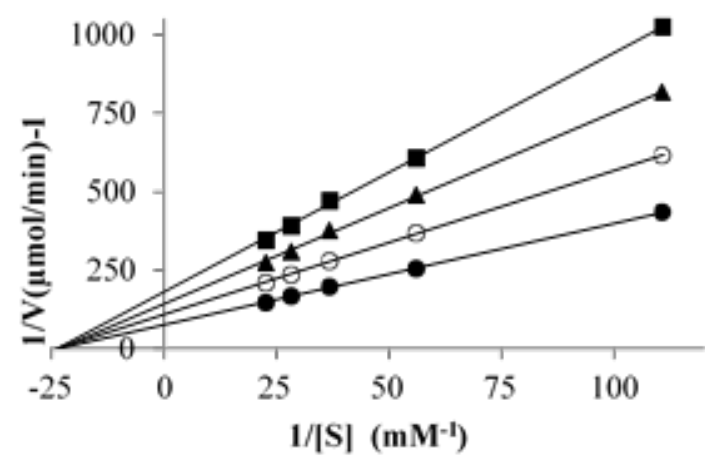

A calcium for cell by blocking the sodium-potassium ATPaz pump and so it leads to rising in spasm $[21,22]$. Also today, drugs containing these active ingredients are frequently used for treatment. The impact of these drug active agents that are often given for treatment on people is gaining importance. The inhibitory effects were studied on Digoxin Glucose 6-Phosphate Dehydrogenase, 6-phosphogluconate dehydrogenase and glutathione reductase enzymes [23]. Besides these, digoxin is a drug used in health care today generally for cardiac insufficiency and atrial fibrillation disorders [24]. Improvement HF (Increasing the awareness and improving the management of heart failure in Europe) research showed that the use of digoxin is most in Turkey among the European Countries [25]. There was not seen a study in literature research for CA I

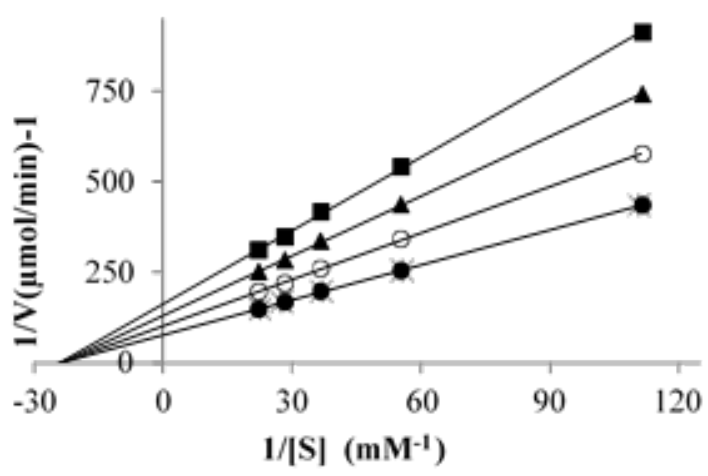

B

Figure 2. Lineweaver-Burk graph for 5 different substrate (ABTS) concentrations and 3 different concentrations for determination of Ki constant, (A) Metoprolol Tartrates and (B) Digoxin. 


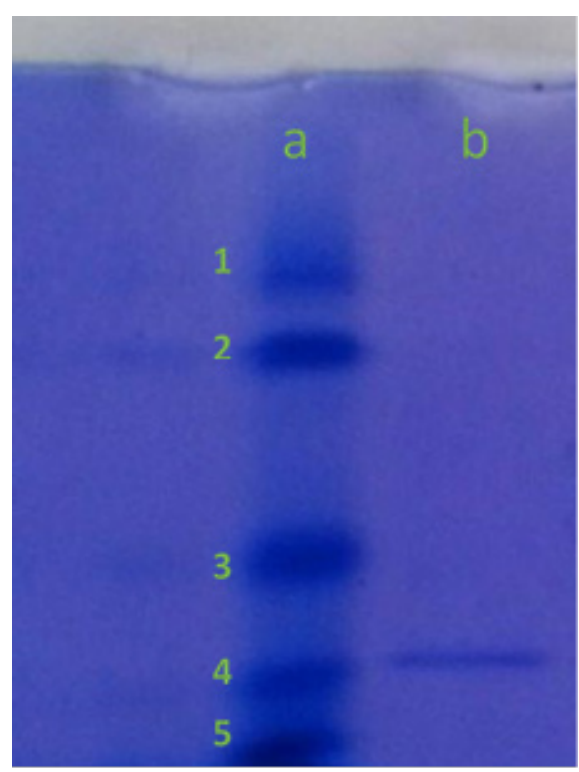

Figure 3. SDS-polyacrylamide gel electrophoresis of Human CA I. Lane a: Standard proteins: 1. Protein B galactosidase (175 kDa), 2. Rabbit fosfofosforilaz B (97 kDa), 3. Bovine Serum Albumin (66 kDa), 4. Bovine Serum carbonic anhydrase (29 kDa), 5. Soybean Tripsd inhibitor (24 kDa), Lanes b: Purified Human Carbonic Anhydrase I (30 kDa).

isoenzymes of two active agents given above. So as to contribute to the literature, we aimed to investigate the in vitro effects of these agents on CA isozyme.

In vitro inhibition effects of drug active substances were investigated on CA-I isoenzymes that purified by affinity techniques from human blood. Two distinct value can be given $\left(\mathrm{K}_{\mathrm{i}}\right.$ ve $I C_{50)}$ to the inhibition effect of active agents which causes the inhibiton. The most practical parameter value is the $I C_{50}$ as studies are carried out in at least two constant inhibitor concentrations in order to determine $\mathrm{K}_{\mathrm{i}}$ constant. The speed values are determined at each constant inhibitor concentration for five distinct substrate concentration. For this purpose substrate concentrations are kept constant, in various concentrations of inhibitors, percent activities are determined and then drug concentration causing $50 \%$ inhibition is calculated with graphs. However it is necessary to calculate the $K_{i}$ values to determine the type of inhibition. The most widely used method is Lineweaver-Burk curves to determine the inhibition type and related $\mathrm{K}_{\mathrm{i}}$ constant. In this method, graph of $1 / \mathrm{V}$ versus $1 /$ [S] is drawn in at least three different constant inhibitor concentrations. Assessments are done from the cut-off points [26]. In our study, what kind of inhibition is shown by active agents was detected with this method. Both of our active agents showed noncompetitive inhibition. Interest of Isoenzyme to substrate did not change $\left(K_{M}=K_{M}{ }^{\prime}\right)$, maximum speed value ( $V \max >V \max$ ) decreased.

\section{CONCLUSION}

When it is examined that the results obtained in the applied drug substances, it obvious that the most powerful inhibitor we tested it on CA I isoenzymes is digoxin $\left(\mathrm{IC}_{50}: 0.045 \mathrm{~mm}\right.$ ) with $50 \%$ reduction of activity at very low concentration. As CA enzyme have vital function in many tissues that involving many of erythrocytes, the results obtained in this study will contribute to a doctors while investigating the causes of the side effects of the drugs on patients.

\section{References}

1. E. Bayram, M. Şentürk, O.I. Küfrevioğlu, C.S. Supuran, In vitro inhibition of salicylic acid derivatives on human cytosolic carbonic anhydrase isozymes I and II, Bioorg. Med. Chem., 16 (2008) 9101-9105.

2. T.A. Coban, S. Beydemir, I. Gülcin, D. Ekinci, A. Innocenti, D. Vullo, C.T. Supuran, Sildenafil is a strong activator of mammalian carbonic anhydrase isoforms I-XIV, Bioorg. Med. Chem., 17 (2009) 5791-5795.

3. J.B. Feldstein, D.N. Silverman, Purification and characterization of carbonic anhydrase from the saliva of the rat, J. Biol. Chem., 259 (1984) 5447-5453.

4. S.R. Krungkrai, N. Suraveratum, S. Rochanakij, J. Krungkrai, Characterization of carbonic anhydrase in plasmodium falciparum, Int. J. Parasitol. Parasites., 31 (2001) 661-668.

5. S. Beydemir, M. Çiftçi, O.I. Küfrevioğlu, M.E. Büyükokuroğlu, Effects of gentamicine sulfate on enzyme activities of carbonic anhydrase from human erythrocytes in vitro and from rat erythrocytes in vivo, Biol. Pharm. Bull., 25 (2002) 966-969.

6. S.B. Oztürk Sarıkaya, F. Topal, M. Şentürk, I. Gülçin, C.T. Supuran, In vitro inhibiton of $\alpha$-carbonic anhydrase isozymes by some phenolic compounds, Bioorg. Med. Chem. Lett., 5 (2011) 4259-4262.

7. A. Telefoncu, Temel ve Uygulamalı Enzimoloji. Ege Üniversitesi, Fen-Edebiyat Fak. Yayını 1986, S. 59.

8. E.E. Keha and O.i. Küfrevioğlu, Biyokimya. Şafak Yayınları, Erzurum, 2000

9. S. Ayvaz, M. Cankaya, A. Atasever, A. Altuntas. 2-Amino-3-cyanopyridine derivatives as carbonic anhydrase inhibitors, J. Enzyme Inhib. Med. Chem., 28 (2013) 305-310.

10. S.B. Sarikaya, M. Sisecioglu, M. Cankaya, I. Gulcin, H. Ozdemir, Inhibition profile of a series of phenolic acids on bovine lactoperoxidase enzyme, J. Enzyme Inhib. Med. Chem., 30 (2015) 479-483. 
11. M. Cankaya, M. Aktas, M. Kuzucu, I. Gül I, T.A Coban, Effects of some drugs on human cord blood erythrocyte carbonic anhydrases I and II: an in vitro study, J. Enzyme Inhib. Med. Chem., 27 (2012) 641-645.

12. E. Dilek, S. Caglar, Effects of mono and dinuclear copper (II) complexes derived from non-steroidal anti-inflammatory drug naproxen on human serum paraoxanase1 (PON1) activity, IntI. J. Pharm. Chem., 5 (2015) 189-195.

13. E. Dilek, M.F. Polat, In Vitro Inhibition Of Three Different Drugs Used In Rheumatoid Arthritis Treatment On Human Serum Paraoxanase 1 Enzyme Activity, Protein. Pept. Lett., 23 (2016) 3-8.

14. M. Ciftçi, O.I. Küfrevioglu, M. Gündogdu, I. Ozmen, Effects of some antibiotics on enzyme activity of glucose-6-phosphate dehydrogenase from human erythrocytes, Pharmacol. Res., 41 (2000) 109-113.

15. J.A. Verpoorte, S. Mehta, J.T. Edsall, Esterase activities of human carbonic anhydrase B and C, J. Biol. Chem. 242 (1967) 4221-4229.

16. M.M.A. Bradford, rapid and sensitive method for the quantitation of microgram quantities of protein utilizing the principle of protein-dye binding, Anal. Biochem., 72 (1976) 248-254.

17. D.K. Laemmli, Cleavage of structural proteins during in assembly of the head of Bacteriophage T4, Nature. 227 (1970) 680-685.

18. I. Gülçin, S. Beydemir, M.E. Büyükokuroğlu, In vitro and in vivo effects of dantrolene on carbonic anhydrase enzyme activities, Biol. Pharm. Bull., 27 (2004) 613-616.
19. T.A. Coban, S. Beydemir, I. Gulcin, D. Ekinci, Morphine inhibits erythrocyte carbonic anhydrase in vitro and in vivo, Biol. Pharm. Bull., 30 (2007) 2257-2261.

20. H. Lineweaver, D.J. Burk, The Determination of Enzyme Dissociation Constants, Am. Chem. Soc., 56 (1934) 658-66.

21. J.W. Hafner, S.M. Belknap, M.D. Squillante, K.A. Bucheit, Adverse drug events in emergency department patients. Ann. Emerg. Med., 39 (2002) 258-267.

22. L. Juntti-Patinen, T. Kuitunen, P. Pere, P.J. Neuvonen, Drug-related visits to a district hospital emergency room, Basic. Clin. Pharmacol. Toxicol., 98 (2006) 212217.

23. S. Adem, M. Ciftci, Purification and Characterization of Glucose 6-Phosphate Dehydrogenase, 6-Phosphogluconate Dehydrogenase, and Glutathione Reductase from Rat Heart and Inhibition Effects of Furosemide, Digoxin, and Dopamine on the Enzymes Activities, J. Biochem. Mol. Toxicol., 30 (2016) 295-301.

24. J.S. Boyle, M.A. Kirk, Digitalis Glycosides. In: J.E. Tintinalli, Tintinalli's Emergency Medicine, A Comprehensive Study Guide, seventh edition, New York, McGraw Hill, 2010, 1260-1264

25. J.B. Segal, The evidence regarding the drugs used for ventricular rate control, J. Fam. Pract., 63 (2003) 1489-1509.

26. D.L. Nelson, M.M. Cox, Lehninger Biyokimyanın İkeleri, 3.Baskı, Palme Yayıncılık, 2004. Page. 259-261. 